\title{
WHITMAN'S NOTES ON EMERSON: AN UNPUBLISHED MANUSCRIPT
}

\author{
ED Folsom
}

THE UNPUBLISHED WHITMAN MANUSCRIPT reproduced on the back cover of this issue was for many years in the possession of Professor Frank Huntley of the University of Michigan. Upon Huntley's death in 1998, the manuscript passed to his son, Professor John Huntley of the University of Iowa, who presented it to me on September 30, 1998. The manuscript was framed (with an 1887 photographic portrait of Whitman by George C. Cox), and printed on the backing of the frame is a caption: "A scrap of Walt Whitman's manuscript. The gift of Horace Traubel, life-long friend and biographer of Whitman."

The page contains what seem to be early (1872) notes toward what would eventually become Whitman's 1880 essay, "Emerson's Books, (The Shadows of Them.)," which appeared in the May 22, 1880, Boston Literary World, in an issue devoted to the celebration of Emerson's birthday. It was reprinted in part in the New York Tribune on May 15, 1882, as "A Democratic Criticism. By Walt Whitman." Finally, it appeared in Specimen Days $\mathcal{E}$ Collect (1882) [PW, 514-518]. Here is a transcription of the manuscript:

[Written on the verso of blank stationery headed: "Department of Justice, Office of the Solicitor of the Treasury, Washington, D.C., , 187 ."]

[At top, set off with a curved line, in blue pencil: ] poems

$\begin{array}{lrr}\text { [At top, in brown ink:] } & 1872 \\ \frac{1819}{3} & \text { [At top, in pencil:] } & 1000 \\ 12000\end{array}$

[Brown ink, added at beginning:] Emerson uses the Deific figure occasionally, but it is only as the intellect in Godlike God's place. [Pencil, main body of text:] The subtlest intellect \& delicacy \& dialectic - the The moral pure \& manly \& fine taste \& manners and the most exquisite poems sense of honor, from the point of view of the [inserted: a] chivalrous stock [inserted: \& \{torn hole: fine?\} tastes and nuances with many subtle conceits,] are all in Emerson's ritings poems-but [illeg.] I should say (at-some risk of being missunderstood) that that the [inserted, in brown ink: normal] sense of Deity \& the Deific which is serves [inserted: the same] in all great [illeg:] imaginative compositions as the quality of Đe heat serves in the Chemical world-is not [inserted, brown ink: cer- 
tainly absent] in them. They are not earth but gems This is why, with all their keenness \& polish [illeg.] almost any some old p psa [inserted, in brown ink: camp meeting] hymn tines or verse from the bible goes [inserted, in brown ink: with electric quickness] quieker, surer \& quieker to the heart than any of them [added, in brown ink: these fine poems.]

[In right margin, by the "chivalrous stock" sentence, in brown ink:] $\mathrm{He}$ is too cautious.

[In left margin, by the "Deity E' the Deific" sentence, in brown ink, set off from text by curved line:] The sense of Deity

[At bottom of page in left-hand corner, in brown ink:] The sense of Deity is indispensable in grand poems - this is what puts [inserted: the book of Job \& much of] the Old Hebrew Bible with the Book of Job-and also the plays of Eschuylus ahead of all poetry we know.

While none of the exact phrasings of the manuscript are used in Whitman's published essay on Emerson, the sentiments are the same. In the essay, Whitman sets out for himself "the ungracious task" of "specify[ing] the shadows on these sunny expanses" of Emerson's writings. He finds Emerson's work "perhaps too perfect, too concentrated." He notes that, while Emerson "has much to say of freedom and wildness and simplicity and spontaneity," still his "performance" is "based on artificial scholarships and decorums at third or fourth removes." In the manuscript, Whitman says Emerson's works are "not earth but gems," a trope he refines and expands in the essay: "It is always a make, never an unconscious growth. It is the porcelain figure or statuette of lion, or stag, or Indian hunter - and a very choice statuette too-appropriate for the rosewood or marble bracket of parlor or library; never the animal itself, or the hunter himself." Whitman's manuscript notes about how Emerson's work lacks the "heat" that "serves in the Chemical world" becomes in the essay a more extended conceit about Emerson's "singularly dandified theory of manners":

He seems to have no notion at all that manners are simply the signs by which the chemist or metallurgist knows his metals. To the profound scientist, all metals are profound, as they really are. The little one, like the conventional world, will make much of gold and silver only.

In the manuscript, Whitman expresses concern with Emerson's lack of the "sense of Deity," his substitution of "intellect" for the "Deific figure," and consequently the inferiority of his work to the Bible and Aeschylus; in the essay this concern is condensed to a simple statement: "At times it has been doubtful to me if Emerson really knows or feels what Poetry is at its highest, as in the Bible, for instance, or Homer or Shakspere." As in the manuscript, where Whitman takes Emerson to task for his "polish" and "keenness" at the expense of "heat," in the essay Whitman castigates Emerson for preferring the "best superb ver- 
bal polish" over true "power" (for which the Concord sage seems only "to have a gentleman's admiration"). Whitman believes that Emerson "always subordinate[s]" "the grandest attribute of God and Poets ... to the octaves, conceits, polite kinks, and verbs" of his writing. The unpublished manuscript, then, lets us see the origins of Whitman's careful recasting of Emerson as the well-meaning writer who was betrayed by his aristocratic and traditional attitudes and preferences.

The University of Iowa 